\title{
Nutritious Pure Herbal Whitening Sun Cream Processed from Seed and Leaf of Moringa oleifera Fortified with Red Rice
}

\author{
Sri Kumalaningsih' ${ }^{1}$, Muhammad Arwani ${ }^{2}$
}

\section{Sri Kumalaningsih", Muhammad Arwani²}

'Department of Agro-industrial Technology Brawijaya University, St Veteran 65145 Malang, East Java, INDONESIA.

${ }^{2}$ Graduate Student of Agricultural Technology, Brawijaya University St Veteran 65145 Malang, East Java, INDONESIA.

\section{Correspondence}

\section{Sri Kumalaningsih}

Veteran Street, Faculty of Agricultural Technology, Brawijaya University, St Veteran 65145 Malang, East Java, INDONESIA.

Phone no: +62-341-580106

Facsimile numbers: $+62-341-568917$

E-mail: kumalaningsih@yahoo.co.id

\section{History}

- Submission Date: 13-08-2017

- Review completed: 11-09-2017;

- Accepted Date: 02-11-2017

DOI : 10.5530/pj.2018.1.15

Article Available online

http://www.phcogj.com/v10/i1

\section{Copyright}

(c) 2018 Phcog.Net. This is an openaccess article distributed under the terms of the Creative Commons Attribution 4.0 International license.

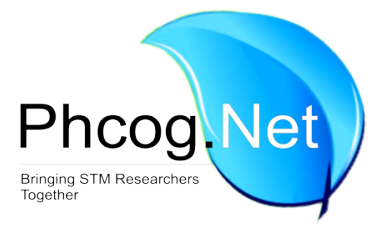

\begin{abstract}
Moringa oleifera seed and leaf contained available medium fatty acid profile and essential amino acid bound in the tissue which should be hydrolysed. The addition of red rice which has antioxidant compound namely $\mathrm{ZnO}$ that can have protected the skin from sun burn and also to make the gelatinous slurry due to reducing the moisture content. The utilization of oil seed and leaf as raw material and fortified with red rice for making a low-cost sun cream is beneficial mainly for women living at rural region. Two phases of experiments were carried out. The first phase was the effect of time and temperature on the yield and oleic acid content of the oil. A randomized block design with two factors was carried out. The temperature at three level $\left(50,55,60^{\circ} \mathrm{C}\right)$ as the first factor, and the time of extraction at three levels $(12,15$, 20 hours) as the second factor. It was found that treatment of $50^{\circ} \mathrm{C}$ at 20 hours extraction shown the best result. The yield of oil was $34 \%$ and the oleic acid content was a $71.9 \%$ from the extracted oil. A randomized block design was used to carried out the second phase of study. The time of steaming $(30,45,60$ minutes) as the first factor and the red rice concentration $(5 \%, 10 \%, 15 \%)$ as the second factor. The result shown that the use of 60 minutes and $5 \%$ red rice concentration was the best result. The slurry has the moisture content of $40.4 \%$ and the protein content was $40.5 \%$. The storage stability of the sun cream stored under low temperature $\left(30 \pm 1^{\circ} \mathrm{C}\right)$ was 6 months and the characteristic of the slurry having oleic acid, essential amino acid and the $\mathrm{ZnO}$.

Key words: Herbal, Moringa oleifera, Red Rice, Sun Cream, ZnO.
\end{abstract}

\section{INTRODUCTION}

Moringa oleifera tree is one of the most important agricultural crops and has been cultivated in india in a long time ago. ${ }^{1}$ This tree has so many potential uses starting from the leaf, stem and also the seeds and pods. $^{2}$ The leaf has essential amino acid compound and used as raw material for few people., ${ }^{3,4}$ Whereas the seed has been extracted for edible oil which has been documented as excellent product, due to contain a medium chain fatty acid, namely oleic acid profile and has been used for cosmetic and also perfume. ${ }^{5}$

In Indonesia Moringa oliefera tree has not yet being cultivated estate crops and non-cultivated plat, grow as shade plants and growth beside on the road side. The leaf and the seed mainly used as vegetable and some time as animal feed. ${ }^{1-3-6}$

Looking at the nutritional value of the seed oil and also the leaf, it is expected the use of the seed oil mix with the young leaf of Moringa tree as raw material for making sun cream is should very nutritious slurry of sun cream. However, the utilization of seed oil and leaf of Moringa for making sun cream has not yet been explored. The extraction of oil from the seed should be control in order the MCFA not being destroyed.?
The temperature and time of extraction of the seed and also the oleic acid contain should be carried out. the seed oil extraction used 70 to $100{ }^{\circ} \mathrm{C}$ is promising, however to protect the oleic acid the used of temperature in the range of 70 to $100^{\circ} \mathrm{C}$ and the time of extraction of 20 hours is therefore may produce high oil but can maintain the decrease of oleic acid. Furthermore, the use of oil and the leaf as raw material for making sun cream need to be fortified with compound having antioxidant activity. Red rice is another valuable compound contain $\mathrm{ZnO}$ and according to Yora, Wahyuni, Afifatul ${ }^{9}$ having high antioxidant activity. The fortification of red rice onto slurry is expected to have an excellent valuable nutritious sun cream. Since red rice not only having an antioxidant activity and also may produce gelatinous compound during melted in heating. However, the time of steaming and the red rice concentration has not yet been evaluated. A combination treatment of concentration of red rice and time for steaming is important to control the non-protein nitrogen (amino acid compound). The aim of this Bhutada, Jadhav, Pinjari, Nemade, Jain ${ }^{8}$ stated for

Cite this article: Kumalaningsih S, Arwani M. Nutritious Pure Herbal Whitening Sun Cream Processed from Seed and Leaf of Moringa oleifera Fortified with Red Rice. Pharmacog J. 2018;10(1):77-80. 
study was to find out the best processing method for making a nutritious high valuable sun cream.

\section{Subjects and Methods Seed oil preparation}

Seed of Moringa oleifera was obtain from Malang region East java province. Cleaned soaked in petroleum ether for 5 hours to softened the peel. The seeds were dried crushed in to powder and then kept in solvent hulls and place in an extraction chamber. The seed oil was mixed with water in ratio 1:1. The mixture of solution containing chloroform: methanol: petroleum ether were purchased from chemical shop. The fatty acid component was determined by gas chromatography (GC), in accordance with AOAC Official Method 2012. ${ }^{10}$

\section{Preparation of Moringa oleifera leaf Powder}

500 grams green leaf of Moringa was blended and dehydrated at $60^{\circ} \mathrm{C}$ and crushed, screened at 60 mesh hole. The procedure used for determining of moisture and protein contain was according to AOAC Official Method 2012. ${ }^{10}$

\section{Slurry preparation}

$50 \mathrm{ml}$ of Moringa oleifera seed oil was mixed with $50 \mathrm{ml}$ water and steamed until the oil was mixed with water. This mixture was then added onto the 200 gram of leaf powder and then added with red rice at a concentration and time of heating according to treatment, placed in a plastic container and then pasteurization under UV light 30 minutes, stored at room temperature.

\section{RESULTS AND DISCUSSION}

As shown in the Table 1, the chemical composition of the oil was excellent. The oil contained $72.9 \%$ oleic acid, $0.7 \%$ linoleic acid, saponification value 181.7 and iodine value 63.7. As expected the oleic acid extracted was $72.9 \%$ it means the method has been carried out excellently because can protect the amount of MCFA which is very important for sun cream. Another factor affected the extraction process is due to the seed is big or mature and also the outer skin is very thin. This influence the powder of the seed is very dried and also the free water is very low. Free water found in the slurry may affected the extraction process. ${ }^{11}$

The extraction of the seed using soxhlet extraction containing mixture of solution petroleum ether, methanol and chloroform has been successfully extracted. This is consistent with the finding obtain by Bhutada, Jadhav, Pinjari, Nemade, Jain. ${ }^{8}$ The temperature used was not ruined the oleic acid. This is consistent with the finding obtained by Bhutada, Jadhav, Pinjari, Nemade, Jain ${ }^{8}$ and also Garba, Medugu, Gwaski, Amusat ${ }^{7}$ mentioned that MCFA mostly stable at temperature not higher than $60^{\circ} \mathrm{C}$, as long as not being exposed to the high temperature.

There was a significant interaction among the treatment on the oleic acid contain. The highest amount was obtained on the treatment of $60^{\circ} \mathrm{C}$ with heated in 20 hours. This result was higher than that obtained by Bhutada, Jadhav, Pinjari, Nemade, Jain. ${ }^{8}$ This is due to the temperature used in this treatment was lower, and the seed was bigger and have soft outer skin. The leaf amino acid was shown in Table 2.

The young leaf of Moringa oleifera contain several essential amino acid shown in Table 3, this finding is consistent with previous research. ${ }^{3}$ All of the essential amino acid found in the young leaf were found not ruined by temperature. Apparently, treatment to led the leaf at room temperature caused the evaporation of free water found in the leaf is not ruin the parenchyma of the leaf, hence may prefund the denaturation of amino acid. This is quite difference if the leaf was blended and then dried, because it will rupture the cell wall and also the amino acid contain.
Table 1: Characterization of oil from seed of Moringa oleifera.

\begin{tabular}{cc}
\hline Components & Percent \\
\hline Specific gravity & 0.8984 \\
Acid value & 3.9 \\
Saponification value & 181.7 \\
Iodine value & 63.7 \\
Unsaponifiable matter & 3.05 \\
Palmitic acid & 7 \\
Stearic acid & 6 \\
Oleic acid & 72.9 \\
Myristic acid & 1.4 \\
Linoleic acid & 0.7 \\
\hline
\end{tabular}

Table 2: Effect of time and temperature on the yield and oleic acid contain.

\begin{tabular}{cccc}
\hline Temperature $\left({ }^{\circ} \mathrm{C}\right)$ & Time (Hours) & Yield (\%) & Oleic Acid (\%) \\
\hline 50 & 12 & $30.4^{\mathrm{a}} \pm 0.08$ & $65.3^{\mathrm{a}} \pm 0.21$ \\
& 16 & $31.3^{\mathrm{b}} \pm 0.12$ & $65.8^{\mathrm{a}} \pm 0.08$ \\
& 20 & $32.2^{\mathrm{c}} \pm 0.17$ & $65.3^{\mathrm{a}} \pm 1.3$ \\
55 & 12 & $32.6^{\mathrm{d}} \pm 0.05$ & $66.7^{\mathrm{a}} \pm 0.08$ \\
& 16 & $33.4^{\mathrm{e}} \pm 0.22$ & $66.9^{\mathrm{b}} \pm 0.05$ \\
& 20 & $34.6^{\mathrm{f}} \pm 0.17$ & $71.8^{\mathrm{c}} \pm 0.08$ \\
60 & 12 & $39.4^{\mathrm{s}} \pm 0.14$ & $74.5^{\mathrm{d}} \pm 0.12$ \\
& 16 & $39.8^{\mathrm{b}} \pm 0.08$ & $76.4^{\mathrm{e}} \pm 0.22$ \\
& 20 & $40.6^{\mathrm{i}} \pm 0.05$ & $76.6^{\mathrm{e}} \pm 0.12$ \\
\hline
\end{tabular}

Values on the same row followed by different superscripts differ significantly at $\mathrm{p} \leq 0.05$ Samples were taken in triplicate and mean \pm standard deviation value reported

Table 3: Amino acids contain in leaf powder.

\begin{tabular}{cc}
\hline Components & 8 gram leaves extract \\
\hline Arginine & 101 \\
Histidine & 41 \\
Isoleucine & 65 \\
Leucine & 154 \\
Lysine & 101 \\
Methionine & 28 \\
Phenylanaline & 110 \\
Threonine & 94 \\
Tryptophan & 35 \\
Valine & 86 \\
\hline
\end{tabular}

The amino acid contain found in the leaf is consistent with the finding obtained by Leone, Spada, Battezzati, Schiraldi, Aristil, Bertoli ${ }^{1}$

The time of steaming at 60 minutes and $15 \%$ concentration of red rice resulted in the lowest moisture content $(40.4 \pm 0.12)$ and the NPN content was $41.5 \pm 0.12$ as shown in Table 4 . After the slurry reached $40 \%$ moisture it was found that the slurry was very viscous and shiny. May be due to the present of red rice in the slurry caused the slurry very viscous. As stated by Saxena ${ }^{12}$ red rice contain amylose and amylopectin compound which could coagulated during the course of heating. The addition of red rice reduces the water contain, but by steering the slurry continuously although NPN was not destroyed. The non-protein containg mainly contain amino acid or ammonia $\left(\mathrm{NH}_{3}\right)$ but the ammonia compound was not detected. Further examination of the sun cream is depicted in Table 5. 
Table 4: Effect of red rice concentration on the moisture contain, protein and non-protein contain of nutritious sun cream

\begin{tabular}{cccc}
\hline $\begin{array}{c}\text { Time of steaming } \\
\text { (Minutes) }\end{array}$ & $\begin{array}{c}\text { Concentration of red rice } \\
(\%)\end{array}$ & Moisture contain (\%) & $\begin{array}{c}\text { Non-Protrein } \\
\text { Nitrogen(g/l) }\end{array}$ \\
\hline 30 & $5 \%$ & $75.2^{\mathrm{a}} \pm 0.08$ & $24.6^{\mathrm{a}} \pm 0.12$ \\
& $10 \%$ & $74.2^{\mathrm{b}} \pm 0.05$ & $23.3^{\mathrm{b}} \pm 0.12$ \\
& $15 \%$ & $72.7^{\mathrm{c}} \pm 0.08$ & $22.6^{\mathrm{c}} \pm 0.08$ \\
45 & $5 \%$ & $68.6^{\mathrm{d}} \pm 0.12$ & $29.2^{\mathrm{d}} \pm 0.08$ \\
& $10 \%$ & $62.5^{\mathrm{e}} \pm 0.12$ & $30.7^{\mathrm{e}} \pm 0.16$ \\
& $15 \%$ & $61.7^{\mathrm{f}} \pm 0.08$ & $31.4^{\mathrm{f}} \pm 0.29$ \\
60 & $5 \%$ & $55.6^{\mathrm{g}} \pm 0.12$ & $39.6^{\mathrm{g}} \pm 0.08$ \\
& $10 \%$ & $53.5^{\mathrm{h}} \pm 0.09$ & $40.5^{\mathrm{h}} \pm 0.25$ \\
& $15 \%$ & $40.4^{\mathrm{i}} \pm 0.12$ & $41.5^{\mathrm{i}} \pm 0.12$ \\
\hline
\end{tabular}

Values on the same row followed by different superscripts differ significantly at $\mathrm{p} \leq 0.05$

Samples were taken in triplicate and mean \pm standard deviation value reported

Table 5: Characterization of nutritious sun cream.

\begin{tabular}{cc}
\hline Components & Percent \\
\hline Oleic acid & 36.4 \\
Myristic acid & 0.7 \\
Linoleic acid & 0.35 \\
Leucine & 154 \\
Lysine & 101 \\
Arginine & 101 \\
ZnO & $370(\mathrm{ppm})$ \\
\hline
\end{tabular}

Table 6: Organoleptic evaluation of sun cream during storage.

\begin{tabular}{ccccc}
\hline Component & Week 1 & Week 2 & Week 3 & Week 4 \\
\hline Compactness & ++++ & ++++ & ++++ & ++++ \\
Odor & ++++ & ++++ & ++++ & ++++ \\
Color & ++++ & ++++ & ++++ & ++++ \\
\hline
\end{tabular}

As shown in Table 5 the characteristic of nutritious sun cream was excellent, mainly on the oleic acid, linoleic acid leucine lysine, arginine and $\mathrm{ZnO}$. In this table, it was shown that the sun cream of made from mixture of seed oil, moringa leaf and fortified with red rice having excellent chemical composition, the oleic acid and linoleic were $36.4 \%$ and $0.35 \%$ respectively, and also contained essential amino acid. The fortification of red rice causes the present of $\mathrm{ZnO}$ which may protect the skin from sun burn.

Based on the organoleptic evaluation the storage stability of sun cream at room temperature was shown at Table 6. It was found that during 1-month period the compactness, odor and color still excellent indicated that there is no environmental factors affect the stability of the sun cream.

\section{CONCLUSION}

The processing of sun cream containing seed oil, young leaf powder and $15 \%$ of red rice shown the best promising sun cream containing MCFA with several amino acids and $\mathrm{ZnO}$.

\section{Recommendations}

Further experiment should be carried out for further study to get detail information about the SPF (sun protective factors) which is found in the natural herbal sun cream and also the impact of the skin after using natural herbal sun cream. From this result above it can be recommended for large production the seed oil extraction should be use hydraulic presser for scaling up the processing.

\section{ACKNOWLEDGEMENT}

The authors thank to Universitas Brawijaya for the publication funding.

\section{CONFLICT OF INTEREST}

There is no conflict of interest regarding the publication of this paper.

\section{ABBREVIATION USED}

MCFA: Medium Chain Fatty Acid; NPN: Non-Protein Nitrogen; UV light: Ultra Violet light; ZnO: Zink Oxide.

\section{REFERENCES}

1. Leone A, Spada A, Battezzati A, Schiraldi A, Aristil J, Bertoli S. Cultivation, Genetic, Ethnopharmacology, Phytochemistry and Pharmacology of Moringa oleifera Leaves: An Overview. International Journal of Molecular Sciences. 2015;16(6):12791-835.

2. Leone A, Fiorillo G, Criscuoli F, et al. Nutritional Characterization and Phenolic Profiling of Moringa oleifera Leaves Grown in Chad, Sahrawi Refugee Camps, and Haiti. International Journal of Molecular Sciences. 2015;16(8):18923-37.

3. Kumalaningsih S, Padaga M, Suprayogi, Rizky VP. Encapsulation of Lactobacillus $\mathrm{sp}$. with Moringa oleifera leaves extract for food supplement. International Research Journal of Agricultural Science and Soil Science. 2011;1(7):273-7.

4. Popoola JO, Obembe OO. Local knowledge, use pattern and geographical distribution of Moringa oleifera Lam. (Moringaceae) in Nigeria. Journal of Ethnopharmacology. 2013;150(2):682-691.

5. Anwar F, Ashraf M, Bhanger MI. Interprovenance variation in the composition of Moringa oleifera oilseeds from Pakistan. Journal of the American Oil Chemists' Society. 2005;82(1):45-51.

6. Leone A, Spada A, Battezzati A, Schiraldi A, Aristil J, Bertoli S. Moringa oleifera Seeds and Oil: Characteristics and Uses for Human Health. Int J Mol Sci. 2016;17(12):21441.

7. Garba AA, Medugu DW, Gwaski PA, Amusat RO. Extraction and characterization of Moringa oleifera seed oil. Applied Research Journal. 2015;1:473-7.

8. Bhutada PR, Jadhav AJ, Pinjari DV, Nemade PR, Jain RD. Solvent assisted extraction of oil from Moringa oleifera Lam. seeds. Industrial Crops and Products. 2016;82:74-80

9. Yora M, Wahyuni S, Afifatul AA. Evaluation of Fe and Zn Contents in Some Red Rice Cultivar from Sumatera Barat. In: Hutabarat B, Hermanto, Susilowati SH, eds. Optimalisasi Sumberdaya Lokal Melalui Diversifikasi Pangan Menuju Kemandirian Pangan dan Perbaikan Gizi Masyarakat Menyongsong Masyarakat Ekonomi ASEAN 2015. Padang, Sumatera Barat (ID): Pusat Sosial Ekonomi dan Kebijakan Pertanian Kementerian Pertanian; 2014:710-8.

10. AOAC. Official Method of AOAC. Gaithersburg, Maryland, USA: AOAC International 2012.

11. Davies DS, Paspek SC, Rappas AS. Water-managed solvent extraction process for organic wastes: Google Patents; 1994.

12. Saxena S [Internet]. New Delhi: NDTV;@ 2017 NDTV [updated 2017 August 11; cited 2017 August 14]. Available from: http://food.ndtv.com/food-drinks/whiterice-brown-rice-or-red-rice-which-one-is-the-healthiest-747933 
GRAPHICAL ABSTRACT

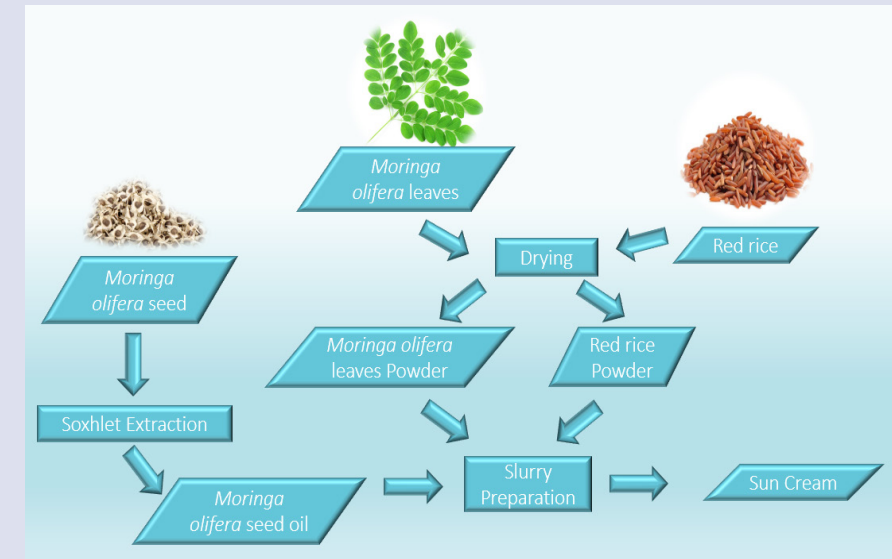

\section{SUMMARY}

- Moringa seed oil with high MCFA profile.

- Moringa leaves powder contain various amino acid.

- Fortification with red rice to produce herbal sun cream.

\section{ABOUT AUTHORS}

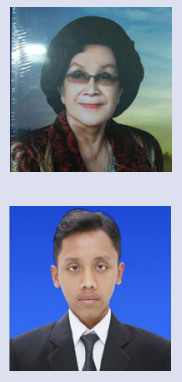

Prof. Sri Kumalaningsih: Is Professor at AgroIndustrial technology, Faculty of Agricultural Technology, Universitas Brawijaya.

Muhammad Arwani: Is graduate student at Agro-Industrial technology, Faculty of Agricultural Technology, Universitas Brawijaya.

Cite this article: Kumalaningsih S, Arwani M. Nutritious Pure Herbal Whitening Sun Cream Processed from Seed and Leaf of Moringa oleifera Fortified with Red Rice. Pharmacog J. 2018;10(1):77-80. 